
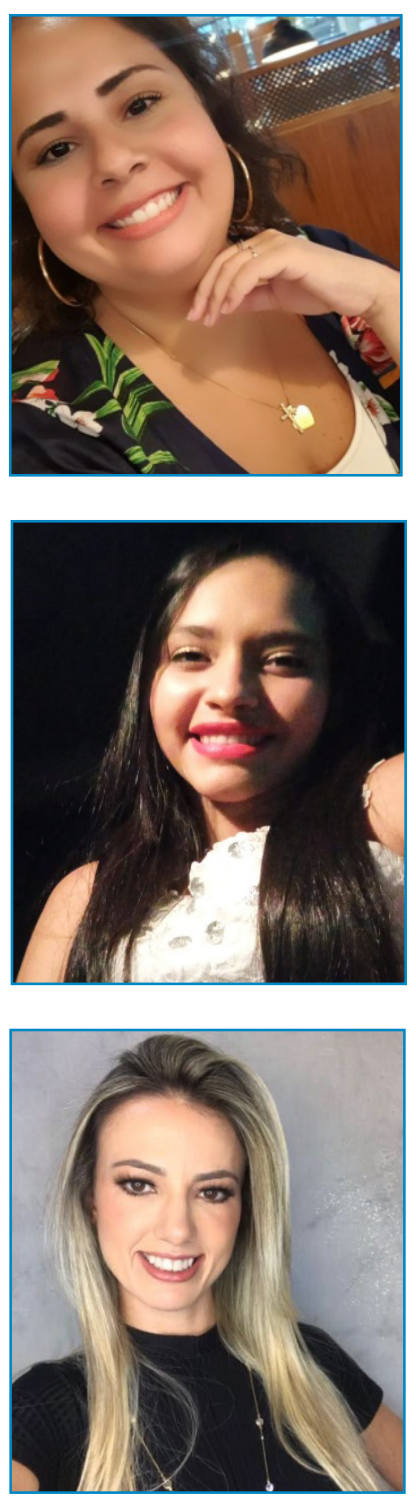

\section{THE SCENARIO OF ACADEMIC STOMATHERAPY LEAGUES IN BRAZIL}

\author{
CENÁRIO DAS LIGAS ACADÊMICAS DE \\ ESTOMATERAPIA NO BRASIL \\ EL ESCENARIO DE LAS LIGAS ACADÉMICAS DE \\ ESTOMATERAPIA EN BRASIL
}

The search for deepening in specific areas has grown substantially in professional training, in order to investigate and share knowledge, together with active participation in practical activities, in order to preserve the inseparability of the teaching-research-extension tripod ${ }^{1}$. Through this perception, strategies were adopted that promote immersion and articulation of knowledge between theory and practice, through the creation of Academic Leagues (AL), which consist of organizations characterized by their own statute, exempt from profit, composed of academics and oriented by professionals who are members of certain institutions, in an extracurricular manner.

The ALs have, in scope, the commitment to society regulated by the Lei de Diretrizes e Bases da Educação Nacional - LDB (Law of Guidelines and Bases of National Education), which establishes as the purpose of higher education the social commitment of universities represented in the form of providing specialized services to the community, in order to establish this relationship of reciprocity ${ }^{2}$. From this perspective, with the proposals for the extension curriculum in the nursing education guidelines, $\mathrm{AL}$ will be strategies to involve students in the world of stomatherapy, so superficially discussed in nursing education.

In Brazil, since 1920, AL are historically linked to medical courses, but there are incipient scientific productions on the subject. Although the relevance of academic training is highlighted, the search for space and implementation of these organizations in the curriculum is still a challenge ${ }^{3}$.

In addition to contributing to the think-how and know-how of students still at the University, empowering them in the training process, AL enables the problematization and, later, transformation of reality based on regional demands.

In the context of stomal therapy nursing, there is an initiative of the Sociedade Brasileira de Estomaterapia/SOBEST (Brazilian Society of Stomatherapy) for registration of AL, which are directly linked to the education department, whose objective is to provide visibility and involve academics, even in the context of graduation, in stomatherapy. Currently, there

\footnotetext{
1.Universidade Federal do Rio de Janeiro - Centro Multidisciplinar UFRJ-Macaé - Instituto de Enfermagem - Macaé (RJ), Brazil.

2.Universidade Regional do Cariri - Faculdade de Enfermagem - Crato (CE), Brazil.

3.Universidade Federal do Ceará - Faculdade de Farmácia, Odontologia e Enfermagem - Departamento de Enfermagem - Fortaleza (CE), Brazil.

*Correspondence author: bispo.alvarez@gmail.com

How to cite: Alvarez AB, Alves CCG, Cavalcante VMV. O cenário das ligas acadêmicas de estomaterapia no Brasil. ESTIMA, Braz. J.

Enterostomal Ther., 2021, 19: e2121. https://doi.org/10.30886/estima.v19.1105_IN
} 
are ten Leagues with registration: Universidade Federal do Rio de Janeiro (Macaé Campus), Universidade Federal do Ceará, Universidade Federal São João Del-Rei (Central-Western Campus Dona Lindu), Universidade Estadual do Ceará, Universidade Regional do Cariri, Universidade Federal do Maranhão, Universidade Estadual do Piauí, Nursing School of the Universidade de São Paulo, Pontifícia Universidade Católica de Minas Gerais - Coração Eucarístico and Liga Acadêmica de Estomaterapia e Tecnologias -LAET of Universidade Federal do Piauí.

Considering that ALs are extremely important entities for excellent training, it is necessary to have the support of professionals who are up-to-date on the area and have proven property to teach and talk about the three pillars of stomatherapy and, for this reason, it shows the importance of stomal therapy ALs to be accredited to SOBEST, since qualified professionals in the area of stomatherapy are linked to this association, in order to offer better support in the development process of ALs.

Furthermore, as a positive aspect in relation to accreditation, there is also the possibility of disseminating the activities developed by an AL through SOBEST's Social Networks, certification for integral members and direct participation in SOBEST events in order to demonstrate excellence of the activities and events promoted by the registered AL.

Thus, it is expected that initiatives for the creation and implementation of AL, in addition to registration with SOBEST, are motivated and replicated so that they can constitute fundamental activities for the dissemination of knowledge about stomatherapy in Brazil, contributing to the training process and positive impacts for future stomatherapists and, consequently, with implications for the care of people with wounds, ostomies or incontinence and for health institutions.

\section{REFERENCES}

1. Panobianco MS, Borges ML, Caetano EA, Sampaio BAL, Magalhães PAP, Moraes DC. A contribuição de uma liga acadêmica no ensino de graduação em enfermagem. Rev Rene. 2013 [citado 03 abr 2021]; 14(1):169-78. Available at: http:// periodicos.ufc.br/rene/article/view/3351/2589

2. Lei n. 9.394 de 20 de dezembro de 1996 (BR). Estabelece as diretrizes e bases da educação nacional. Diário Oficial da União [periódico na internet], Brasília (DF). 23 dez 1996 [citado 03 abr 2021]. Available at: http://www.planalto.gov.br/ ccivil_03/leis//9394.htm

3. Vieira CB, Silva DA. Contribuições de uma liga acadêmica do trauma e emergência na formação universitária: percepção dos integrantes. Revista Nursing. 2009 [citado em 03 abr 2021]; 22(259):3384-8. Available at: http://www.revistanursing. com.br/revistas/259/pg26.pdf 